\title{
Febrile Ulceronecrotic Mucha-Habermann Disease: A Rare Case Report and Review of Cases Treated With Oral Cyclosporine
}

\author{
Apasee Sooksamran, M.D. ${ }^{1}$, Poonnawis Sudtikoonaseth, M.D. ${ }^{1}$, Praneet Sajjachareonpong, M.D. ${ }^{2}$, \\ Tanongkiet Tienthavorn, M.D. ${ }^{1}$
}

'Department of Medical Services, Institute of Dermatology, Phayathai, Bangkok 10400, Thailand.

${ }^{2}$ Skin Clinic, Phayathai 2 International Hospital, Phayathai, Bangkok 10400, Thailand.

Received 12 January 2021 • Revised 16 February 2021 • Accepted 17 February 2021 • Published online 17 May 2021

\begin{abstract}
:
We present a case of febrile ulceronecrotic Mucha-Habermann disease who presented with widespread erythematous crusted papules, which rapidly progressed to ulceronecrotic lesions accompanied by fever. The serologies showed high titers of cytomegalovirus IgG $(>1: 3,200)$ and $\lg M(1: 800)$. The histopathological study showed epidermal necrosis. The treatment was begun with systemic steroids and roxithromycin to which the patient did not respond. After switching the treatment to methotrexate, the patient was further complicated by getting hepatitis. Low dose cyclosporine resolved the situation within 2 weeks. In patients for whom methotrexate is contra-indicated or ineffective, cyclosporine can suppress T-lymphocyte hyperresponsiveness and resolve this disease.
\end{abstract}

Keywords: cyclosporine, cytomegalovirus, febrile ulceronecrotic Mucha-Habermann disease, Pityriasis lichenoides with ulceronecrosis and hyperthermia

Contact: Apasee Sooksamran, M.D.

Department of Medical Services, Institute of Dermatology, Phayathai, Bangkok 10400, Thailand.

E-mail: dr.apasee@gmail.com

(c) 2021 JHSMR. Hosting by Prince of Songkla University. All rights reserved.

This is an open access article under the CC BY-NC-ND license

(http://www.jhsmr.org/index.php/jhsmr/about/editorialPolicies\#openAccessPolicy).
J Health Sci Med Res 2022;40(1):89-94 doi: 10.31584 /jhsmr.2021811 www.jhsmr.org 


\section{Introduction}

Febrile ulceronecrotic Mucha-Habermann disease (FUMHD), also known as pityriasis lichenoides with ulceronecrosis and hyperthermia, is a severe fatal variant of pityriasis lichenoides et varioliformis acuta (PLEVA). The histopathological features of FUMHD are similar to PLEVA but clinically distinct because of rapid disease progression to ulceronecrotic polymorphic lesions combined with fever. Systemic and mucous membrane involvement are varieties and patients may not have a previous history of PLEVA. ${ }^{1}$ Its etiology remains unclear, the most likely proposed hypothesis' suggests it may result from CD8+ T cell hyperresponsiveness to infectious pathogens such as Epstein-Barr virus (EBV), cytomegalovirus (CMV), measles, varicella-zoster virus (VZV), parvovirus B19, adenovirus, toxoplasma or the human immunodeficiency virus (1). About 70 cases have been reported to date, with over half occurring in children and adolescents. ${ }^{2-4}$ The cases in children had less mucosal involvement, less vasculitis and better prognosis compared with older (>40 years) patients, who also had higher mortality (mostly from sepsis). ${ }^{5,6}$ Due to the rarity of FUMHD, there are currently no practice guidelines or standard treatments. Various treatment approaches have been tried and published in the literature case reports, such as systemic steroids, methotrexate, cyclosporine, cyclophosphamide, antibiotics, acyclovir, dapsone, pentoxifylline, and phototherapy. ${ }^{1}$ Of these, methotrexate appears to be the most effective. ${ }^{1}$ Herein, we report a complicated case who was unresponsive to a combination of systemic steroids and antibiotics, and who developed hepatitis after a low dose of methotrexate. Finally, she responded dramatically to a combination of cyclosporine and systemic steroid.

\section{Case Report}

A 20-year-old Thai female presented with progressive itchy red bumps scattered over her body for 3 weeks. After visiting a dermatologist, she was diagnosed with pityriasis lichenoides, and was treated with topical steroids and an oral antihistamine for a week. However, her condition did not respond to the treatment, and the lesions progressed to blisters and generalized ulceration on her trunk excluding her eyes, mouth and genitalia. She was then prescribed prednisolone $20 \mathrm{mg} /$ day for 5 days, but her symptoms worsened, as she developed a highgrade fever with no organ-specific symptoms, and finally she was admitted to our in-patient department for further investigations.

On admission, her body temperature was 38.8 ${ }^{\circ} \mathrm{C}$, her pulse rate was $100 / \mathrm{min}$, her respiratory rate was $20 / \mathrm{min}$, and blood pressure $128 / 80 \mathrm{~mm} / \mathrm{Hg}$. Other physical examinations were within normal parameters, other than the dermatological examination, which found generalized multiple well-defined coalescent papulopustular ulceronecrotic plaques with vesicles, hemorrhagic crusts on approximately $80.0 \%$ of her face, trunk and extremities with prominent flexural accentuation (Figure 1A). No mucosal involvement was found. The clinician's impression was FUMHD, with a differential diagnosis including VZV, primary cutaneous CD8+ aggressive epidermotropic cytotoxic $T$ cell lymphoma, hydroa vacciniforme-like lymphoproliferative disorders, and lymphomatoid papulosis.

Complete laboratory examinations were done to rule out infections. A Tzanck smear from the vesicles showed no acantholytic cells and no multinucleated giant cells. A Gram stain from the lesions showed Gram-positive cocci and Gram-negative bacilli. The bacterial culture of the lesions reported Pseudomonas aeruginosa and methicillinresistant Staphylococcus aureus. Her complete blood count showed mild lymphocytosis. A blood culture showed no bacterial growth. Her chest $\mathrm{X}$-ray revealed no active infiltration. Serological studies for viral infections including EBV, toxoplasmosis, parvovirus B19, mycoplasma, herpes simplex virus, VZV, human immunodeficiency, hepatitis C 

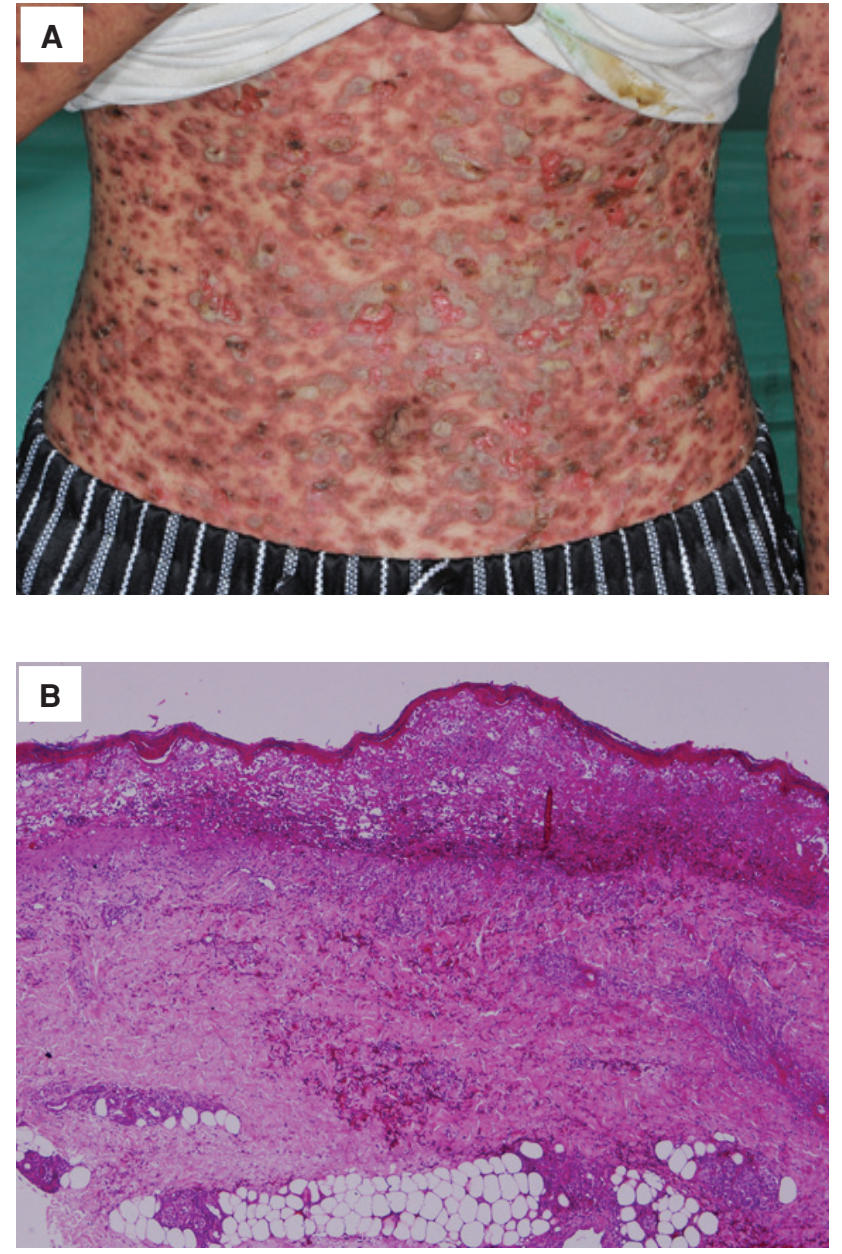

Figure 1 (A) The dermatological examination found generalized multiple well-defined coalescent ulceronecrotic plaques with papules pustules, vesicles and hemorrhagic crusts on her trunk and extremities. (B) Histopathology reported focal parakeratosis, epidermal necrosis, and vacuolar-interface dermatitis. The superficial and deep perivascular areas had lymphohistiocytic nfiltration with prominent extravasation of red blood cells and fibrinoid deposits at the vascular walls. and hepatitis B virus were all negative. However, a serum immunofluorescence assay was positive for both CMV $\lg (>1: 3,200$, reference range $<1: 100)$ and $\lg M(1: 800$, reference range $<1: 100)$. However, her polymerase chain reaction (PCR) for $\mathrm{CMV}$ in the blood was negative. The ophthalmologic examination found no evidence of CMV retinitis. A second skin biopsy was done on new necrotic lesions, and reported focal parakeratosis, epidermal necrosis, and vacuolar-interface dermatitis (Figure 1B). The superficial and deep perivascular area had lymphohistiocytic infiltration with prominent extravasation of red blood cells with fibrinoid deposits at the vascular walls. An immunohistochemical study for lymphocytes showed strong labeling with CD8 but negative for CD4 and CD30. A special immunostaining for CMV was negative. Repeated serological titers a month later showed negative for CMV IgM but a persisting high reading of CMV IgG $(>1: 3,200)$.

After the diagnosis of FUMHD was confirmed, intravenous dexamethasone $8 \mathrm{mg} /$ day, oral roxithromycin, and colchicine were prescribed, but without response over 2 weeks, so a methotrexate $5 \mathrm{mg} /$ week testing dose was tried. Seven days after the methotrexate was begun, her transaminase enzymes had become elevated and the methotrexate was discontinued, along with the roxithromycin and colchicine because drug-induced liver toxicity was suspected. Because of her hepatitis, a low dose of cyclosporine $2.25 \mathrm{mg} / \mathrm{kg} /$ day (MKD) was added in combination with the prednisolone $1 \mathrm{MKD}$. After 2 weeks of the cyclosporine, her skin lesions were improving and her fever had subsided. She had also developed secondary skin infections during her illness, which responded well to meropenem and vancomycin, adjusted according to susceptibility test results. There remained only varioliform scars over her face, trunk and distal extremities. Her prednisolone $1 \mathrm{MKD}$ was tapered down to $0.67 \mathrm{MKD}$ over 2 weeks and gradually stopped within 2 months. There was no further damage to her liver function or other complications resulting from the cyclosporine. 


\section{Discussion}

The main clue for FUMHD is a history of pityriasis lichenoides with rapid progression to ulceronecrotic lesions that have flexural accentuation accompanied with fever. ${ }^{1}$ In our case we ruled out varicella following a negative VZV titer. Primary cutaneous CD8+ aggressive epidermotropic cytotoxic $\mathrm{T}$ cell lymphoma was unlikely because there were no monomorphous atypical lymphocytes in the tissue examined. Also, the inflammatory cells showed negative CD30 staining, thus, an additional contraindication for a diagnosis of lymphomatoid papulosis. Additionally, our case had predominantly sunprotected lesions rather than sunexposed lesions and a negative finding for EBV infection from the serology, which were contrary to a diagnosis of Hydroa vacciniforme.

Our case was eventually confirmed as FUMHD by histopathology which was similar to PLEVA. ${ }^{1}$ As the hypothesis of CD8+ $\mathrm{T}$ cell hyperresponsiveness to an infectious agent can be the etiology of PLEVA suggests ${ }^{1}$, we found positive test results for CMV in our case. A previous study by Tsai et al. found that the clinical presentation of FUMHD with additional arthritis that was precipitated by a CMV infection was confirmed by the increased IgG titer for CMV and positive immunostaining and PCR from the lesions. ${ }^{7}$ This was in contrast to our case, however, as our patient had no arthritis and had persistently high

Table 1 Review of febrile ulceronecrotic Mucha-Habermann cases treated with Cyclosporin

\begin{tabular}{|c|c|c|c|c|c|c|}
\hline Case & Age & Patient setting & $\begin{array}{l}\text { CsA dose } \\
\text { (level } \mathrm{ng} / \mathrm{ml})\end{array}$ & $\begin{array}{l}\text { CsA } \\
\text { duration }\end{array}$ & Treatment & Progression \\
\hline Herron $2005^{12}$ & $8 y$ & $\begin{array}{l}\text {-Severe lesions } \\
\text {-Elevated serum IL2 } \\
\text { receptor level }\end{array}$ & $\begin{array}{l}3 \mathrm{MKD} \text { increase to } \\
6 \mathrm{MKD} \\
(47-152 \mathrm{ng} / \mathrm{ml})\end{array}$ & NA & $\begin{array}{l}\text { Induction: } \\
\text { MTX and CsA } \\
\text { Maintenance:MTX }\end{array}$ & Developed PLC \\
\hline $\operatorname{Kim} 2007^{13}$ & $8 \mathrm{y}$ & $\begin{array}{l}\text {-Did not respond to } \\
\text { SS and ATBs }\end{array}$ & $\begin{array}{l}2.5 \mathrm{MKD} \text { then decrease } \\
\text { to } 1.25 \mathrm{MKD}\end{array}$ & $1 \mathrm{wk}$ & $\begin{array}{l}\text { Induction: } \\
\text { SS, ATBs, CsA } \\
\text { Maintenance: } \\
\text { SS }\end{array}$ & $\begin{array}{l}1 \text { month } \\
\text { free of disease }\end{array}$ \\
\hline Uzoma $2014^{14}$ & $13 y$ & -Mildly elevated LFT & $3 \mathrm{MKD}$ & 3 wks & $\begin{array}{l}\text { Induction: } \\
\text { Pentoxifylline, } \\
\text { CsA and NBUVB } \\
\text { Maintenance: NBUVB }\end{array}$ & $\begin{array}{l}30 \text { months } \\
\text { free of disease }\end{array}$ \\
\hline Lode $2015^{15}$ & 20 mos & $\begin{array}{l}\text {-Did not respond to } \\
\text { acyclovir, IVIG }\end{array}$ & $\begin{array}{l}2.5 \mathrm{MKD}(27 \mathrm{ng} / \mathrm{ml}) \text { then } \\
\text { decreased to } 1.25 \mathrm{MKD} \\
(54 \mathrm{ng} / \mathrm{ml})\end{array}$ & $3 \mathrm{mos}$ & CsA and prednisolone & $\begin{array}{l}4 \text { years free of } \\
\text { disease }\end{array}$ \\
\hline Nofal $2016^{6}$ & $9 \mathrm{y}$ & $\begin{array}{l}\text {-Did not respond to } \\
\text { ATBs and SS }\end{array}$ & NA & $1 \mathrm{wk}$ & $\begin{array}{l}\text { Azithromycin, SS, IVIG, } \\
\text { CsA }\end{array}$ & Death \\
\hline Our case & $20 y$ & $\begin{array}{l}\text {-Did not respond to } \\
\text { ATBs, SS and } \\
\text { colchicine } \\
\text {-Hepatitis from MTX }\end{array}$ & $\begin{array}{l}2.25 \mathrm{MKD} \\
(24 \mathrm{ng} / \mathrm{ml})\end{array}$ & 3 mos & CsA and prednisolone & $\begin{array}{l}\text { Improved during } \\
3 \text { months } \\
\text { observation }\end{array}$ \\
\hline
\end{tabular}

$M K D=m g / k g / d a y, M T X=m e t h o t r e x a t e, N A=n o t$ assessed, PLC=pityriasis lichenoides chronica, IL2=interleukin2, LFT=liver function test, NBUVB=Narrowband ultraviolet B phototherapy, SS=systemic steroid, ATB=antibiotics, IVIG=intravenous immunoglobulin, CsA=cyclosporine 
titers of CMV IgG $(>1: 3,200)$ and CMV IgM (1:800), with the CMV IgM returning to normal within a month. Our case suggests that these high titers were not because of a primary infection, but could have been from reactivation or reinfection by different strains. ${ }^{8-10}$ There are no protocols for treatment or monitoring for CMV reactivation or reinfection in cases of FUMHD. Because of no viremia, and suspected hypersensitivity of the patient to this disease, we chose to continue using systemic steroids with another immunosuppressive agent. Cyclosporine has the ability to suppress T-lymphocyte activation, which was related to the pathogenesis of the disease. ${ }^{11}$

Our patient is the fifth reported FUMHD case responsive to cyclosporine, according to previously published data described in Table 1.,12-15 Lode et al. used the longest 3-months regimen of low dose cyclosporine with prednisolone which resulted in the best result of the longest disease-free period of 4 years. However, this result may have been because of the extended follow-up time period compared with the other cases. ${ }^{15}$ There was a fatal case reported by Nofal et al. that was from Pseudomonas aeruginosa septicemia. Following the results of a previous case successfully treated by Lode et al. $^{15}$, we also prescribed low dose cyclosporine and prednisolone for 3 months in order to avoid recurrence while monitoring the patient for infection and renal and liver functions. As of the date of this writing, February 2021, the patient has suffered no recurrence or complications.

\section{Conclusion}

We present a case of FUMHD with transaminitis who was intolerant to methotrexate, but had a dramatic response to low dose cyclosporine. This is the fifth report of FUMHD successfully treated by the combination of cyclosporine and prednisolone, although there has also been one report of a patient who died following the use of cyclosporine. Although immunosuppressive agents are required to control FUMHD, the infection needs to be detected early and the patient given timely treatment in order to avoid a fatal outcome. The role of CMV re-activation and re-infection associated with FUMHD needs to be further studied. Additionally, the protocols of antiviral therapy in cases of FUMHD still need to be clarified.

\section{References}

1. Nofal A, Assaf M, Alakad R, Amer H, Nofal E, Yosef A. Febrile ulceronecrotic Mucha-Habermann disease: proposed diagnostic criteria and therapeutic evaluation. Int J Dermatol 2016;55: 729-38.

2. Perrin BS, Yan AC, Treat JR. Febrile ulceronecrotic MuchaHabermann disease in a 34-month-old boy: a case report and review of the literature. Pediatr Dermatol 2012;29:53-8.

3. Yamada K, Motegi S, Matsushima Y. Febrile ulceronecrotic Mucha-Habermann disease in a young boy: a case report and review of the literature. Acta Derm Venereol 2014;94:603-4.

4. Dupin A, Bosset D, Atger L, Chevallier B, Saiag P, Benoist G. Febrile ulceronecrotic Mucha-Habermann disease. Arch Pediatr 2016;23:82-5.

5. Yang CC, Lee JY, Chen W. Febrile ulceronecrotic MuchaHabermann disease with extensive skin necrosis in intertriginous areas. European J Dermatol 2003;13:493-6.

6. Nofal A, Alakad R, Assaf M, Nofal E. A fatal case of febrile ulceronecrotic Mucha-Habermann disease in a child. JAAD Case Rep 2016;2:181-5.

7. Tsai KS, Hsieh HJ, Chow KC, Lin TY, Chiang SF, Huang HH. Detection of cytomegalovirus infection in a patient with febrile ulceronecrotic Mucha-Habermann's disease. Int $\mathrm{J}$ Dermatol 2001;40:694-8.

8. De Paschale M, Agrappi C, Manco MT, Clerici P. Positive predictive value of anti-HCMV $\operatorname{lgM}$ as an index of primary infection. J Virol Methods 2010;168:121-5.

9. Marchetti S, Santangelo R, Manzara S, D'Onghia S, Fadda G, Cattani P. Comparison of real-time PCR and pp65 antigen assays for monitoring the development of Cytomegalovirus disease in recipients of solid organ and bone marrow transplants. New Microbiol 2011;34:157-64.

10. Ljungman P, Boeckh M, Hirsch HH, Josephson F, Lundgren J, Nichols G, et al. Definitions of Cytomegalovirus Infection and 
Disease in Transplant Patients for Use in Clinical Trials. Clin Infect Dis 2017;64:87-91.

11. Amarapal P, Tantivanich S, Balachandra K. Prevalence of cytomegalovirus in Thai blood donors by monoclonal staining of blood leukocytes. Southeast Asian J Trop Med Public Health $2001 ; 32: 148-53$.

12. Herron MD, Bohnsack JF, Vanderhooft SL. Septic, CD-30 positive febrile ulceronecrotic pityriasis lichenoides et varioliformis acuta. Pediatr Dermatol 2005;22:360-5.

13. Kim HS, Yu DS, Kim JW. A case of febrile ulceronecrotic
Mucha-Habermann's disease successfully treated with oral cyclosporin. J Eur Acad Dermatol Venereol 2007;21:272-3.

14. Uzoma MA, Wilkerson MG, Carr VL, Westhoven GS, Raimer SA. Pentoxifylline and cyclosporine in the treatment of febrile ulceronecrotic Mucha-Habermann disease. Pediatr Dermatol 2014;31:525-7.

15. Lode HN, Doring $P$, Lauenstein P, Hoeger P, Dombrowski $F$, Bruns R. Febrile ulceronecrotic Mucha-Habermann disease following suspected hemorrhagic chickenpox infection in a 20-month-old boy. Infection 2015;43:583-8. 